\title{
MODEL INTEGRASI EKONOMI MARITIM DAN PARIWISATA DI DAERAH GUNA PENINGKATAN EKONOMI INDONESIA TIMUR
}

\author{
I Nyoman Sudapet, Agus Sukoco, Ikhsan Setiawan \\ Universitas Narotama Surabaya \\ Email: ikhsan.setiawan@narotama.ac.id
}

\begin{abstract}
Maritime economic growth and increasing tourism economy Marine Highway program are supported. BPS data (2016) states the number of foreign tourists visiting Indonesia during January-April 2016 reached 3.52 million visits, up 7.51 percent compared with the number of foreign tourists in the same period in 2015, which totaled 3.27 million visits. Additionally related maritime economy, the data agency said the number of goods transported in domestic shipping April 2016 reached 20.8 million tons, up 1.98 percent compared to the previous month and rose 16.50 percent over the same month in 2015. Growth in Indonesia east must be used optimally by the Government to develop a model of economic integration Maritime and Tourism. This study aims at modeling, mapping and economic feasibility of the Maritime Economic Integration and Tourism in the area in order to improve the economy of Eastern Indonesia, with the manufacture of a Geographic Information System that supports the economic development. The study was conducted in the years 2017-2018, Year The first is modeling, mapping and analysis of the feasibility of Economic Integration Model Maritime and tourism in the area in order to improve the economy of eastern Indonesia. result in Research published in the Seminar / International Proceedings, International Journal Scopus indexed and submitted to the Ministry of Justice and Human Rights to obtain IPR Copyright on the application of Geographic Information Systems Integration development of Maritime Economy and Tourism in Eastern Indonesia.
\end{abstract}

\section{Keywords: Economic Integration, Tourism Economics, Economics Maritime}

\begin{abstract}
Abstrak
Pertumbuhan ekonomi maritim dan ekonomi pariwisata semakin meningkat didukung program Tol Laut. Data BPS (2016) menyatakan jumlah kunjungan wisman ke Indonesia selama Januari-April 2016 mencapai 3,52 juta kunjungan atau naik 7,51 persen dibandingkan dengan jumlah kunjungan wisman pada periode yang sama tahun 2015, yang tercatat sebanyak 3,27 juta kunjungan. Selain itu terkait ekonomi maritim, data BPS menyatakan jumlah barang yang diangkut pelayaran dalam negeri April 2016 mencapai 20,8 juta ton atau naik 1,98 persen dibandingkan bulan sebelumnya dan naik 16,50 persen dibandingkan bulan yang sama tahun 2015. Pertumbuhan ekonomi di Indonesia Timur harus dimanfaatkan secara optimal oleh Pemerintah dengan mengembangkan Model Integrasi Ekonomi Maritim dan Pariwisata. Penelitian ini bertujuan melakukan pemodelan, pemetaan dan kelayakan ekonomis Integrasi Ekonomi Maritim dan Pariwisata di daerah guna peningkatan ekonomi Indonesia Timur, disertai pembuatan Sistem Informasi Geografis yang mendukung pengembangan ekonomi tersebut. Penelitian dilakukan dalam tahun 2017-2018, Tahun Pertama adalah pemodelan, pemetaan dan analisis kelayakan Model Integrasi Ekonomi Maritim dan Pariwisata di daerah guna peningkatan ekonomi Indonesia Timur. Hasil penelitian dipublikasikan dalam Seminar/Proceeding Internasional, Jurnal Internasional terindex Scopus, serta diajukan
\end{abstract}


ke Kementerian Hukum dan HAM untuk mendapatkan HKI Hak Cipta atas aplikasi Sistem Informasi Geografis pengembangan Integrasi Ekonomi Maritim dan Pariwisata di Indonesia Timur.

\section{Keywords: Integrasi Ekonomi, Ekonomi Pariwisata, Ekonomi Maritim}

\section{A. Latar Belakang}

Data BPS (2016) menyatakan jumlah kunjungan wisman ke Indonesia selama Januari-April 2016 mencapai 3,52 juta kunjungan atau naik 7,51 persen dibandingkan dengan jumlah kunjungan wisman pada periode yang sama tahun 2015, yang tercatat sebanyak 3,27 juta kunjungan. Selain itu terkait ekonomi maritim, data BPS menyatakan jumlah barang yang diangkut pelayaran dalam negeri April 2016 mencapai 20,8 juta ton atau naik 1,98 persen dibandingkan bulan sebelumnya dan naik 16,50 persen dibandingkan bulan yang sama tahun 2015 (BPS, 2016). Akselerasi penyerapan belanja pemerintah terutama terkait pembangunan infrastruktur akan mendorong perbaikan investasi dan usaha konstruksi. Pemulihan ekonomi negara tujuan ekspor utama juga diprakirakan akan mendorong ekspor luar negeri serta kinerja Industri Pengolahan (BI, 2016). Pertumbuhan ekonomi yang stabil, politik-keamanan yang relatif terkendali, sumber daya alam yang kaya dan iklim investasi yang kuat telah meningkatkan jumlah penduduk kelas menengah di Indonesia. Peningkatan penduduk kelas menengah membawa gelombang belanja konsumen dalam bentuk pemilikan/investasi properti, kebutuhan jasa/konsultasi keuangan serta pendidikan (Rastogi, et al, 2013)

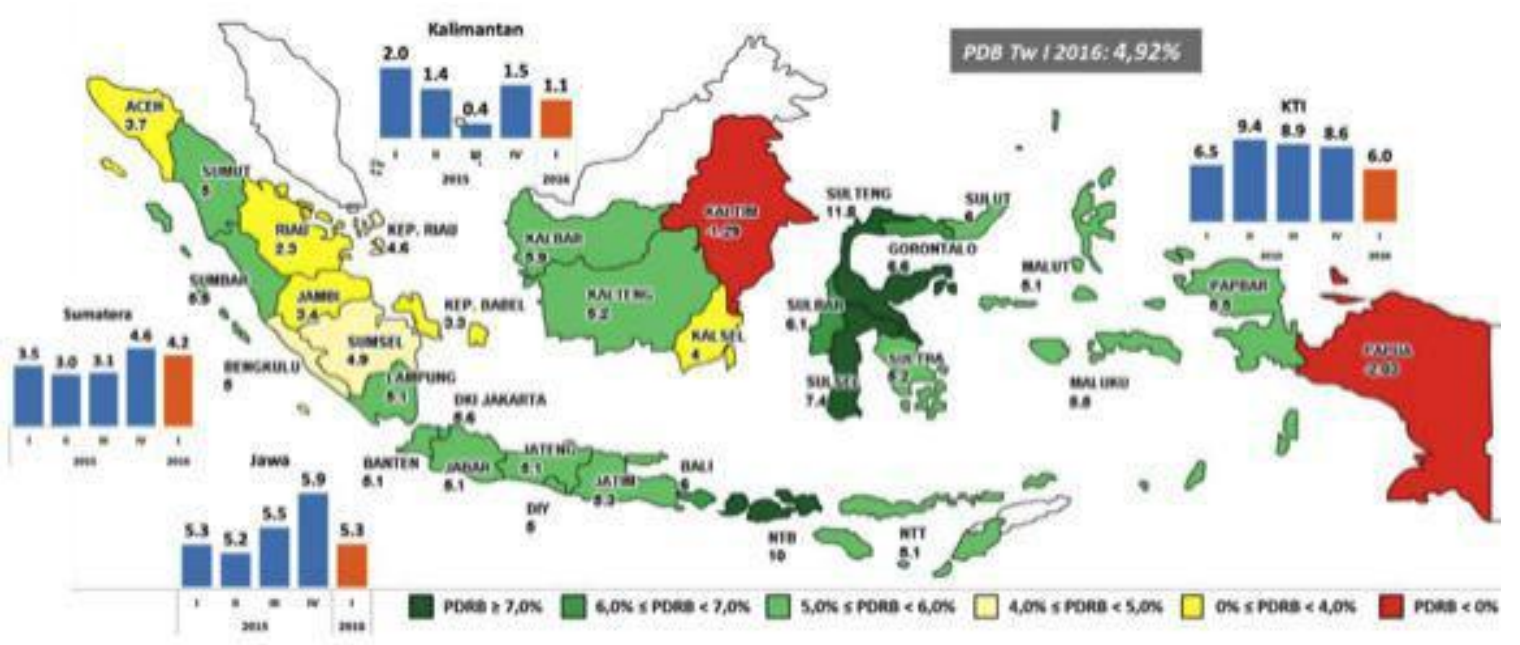

Gambar 1. Pertumbuhan Ekonomi Daerah (Triwulan I tahun 2016)

Sumber : BI, 2016 
Pertumbuhan ekonomi di Indonesia Timur terkait Ekonomi Maritim dan Ekonomi Pariwisata, didominasi wilayah Jawa Timur dan Bali. Ekonomi pariwisata di Jawa Timur tergambarkan melalui tingkat penghunian kamar (TPK) hotel berbintang di Jawa Timur pada triwulan I 2016 mencapai 56,07\% lebih tinggi dibandingkan periode yang sama pada tahun sebelumnya yaitu 53,09\%. Pertumbuhan kunjungan wisatawan mancanegara ke Indonesia melalui Bandara Juanda mencapai 6,66\% dengan wisatawan terutama berasal dari Malaysia $(23,04 \%)$ dan Singapura (10,53\%). Ekonomi maritim di Jawa Timur, tergambarkan pada arus barang yang keluar dari Tanjung Perak mengalami pertumbuhan dari periode yang sama di tahun 2015, dari $-31,83 \%$ menipis penurunannya menjadi $2,65 \%$.
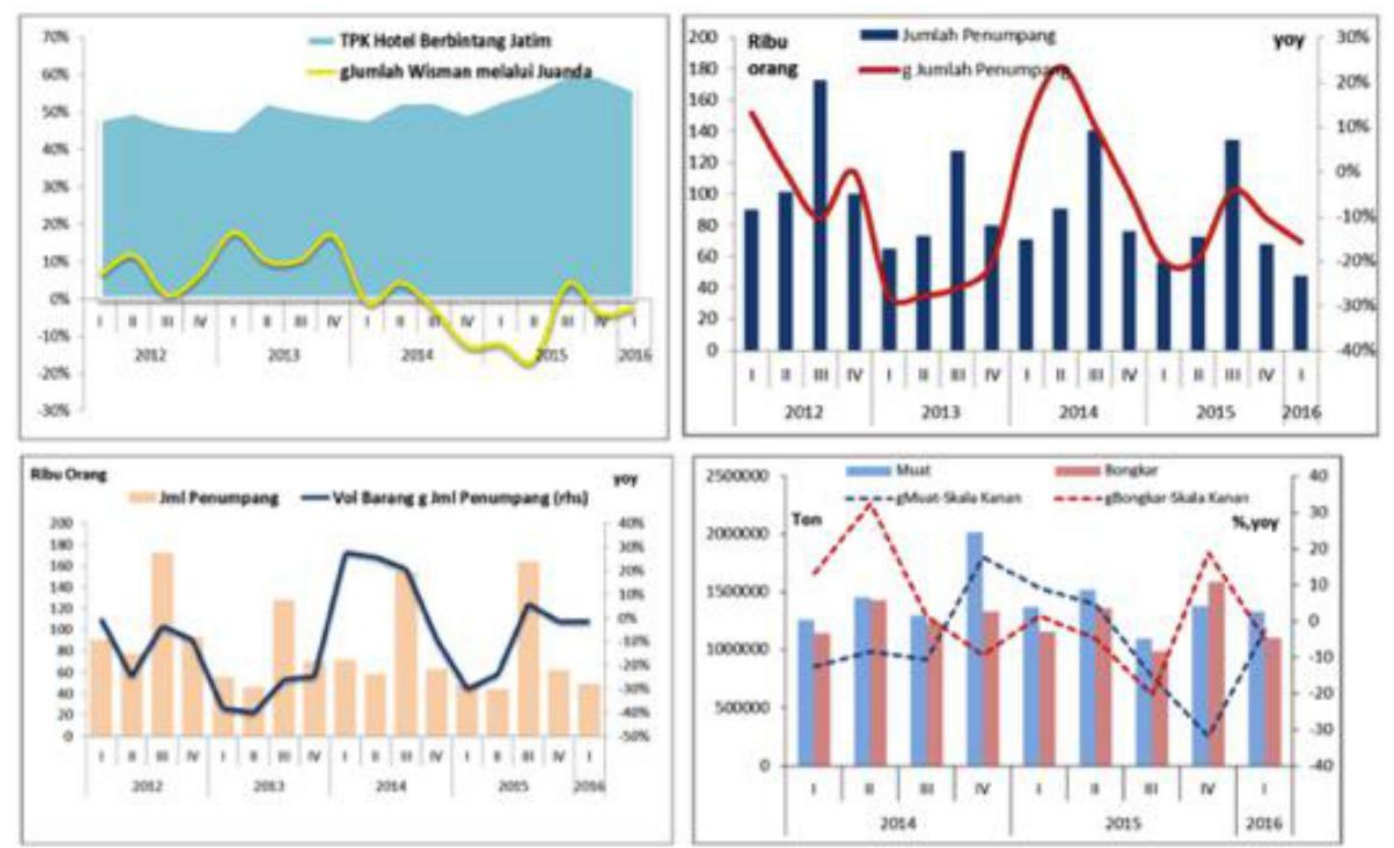

\section{Gambar 2. Pertumbuhan Ekonomi Pariwisata (Hotel \& Wisman) dan Maritim (Pelabuhan Tanjung Perak) di Jawa Timur Sumber : BI, 2016}

Ekonomi Pariwisata di Bali, mengalami peningkatan didorong oleh adanya event hari raya dan liburan sepanjang triwulan I 2016. Perayaan imlek mendorong peningkatan jumlah wisman asal Tiongkok ke Bali sejalan dengan peningkatan direct flight dan chartered flight dari dan ke Bali dari beberapa kota di Tiongkok. Hari raya keagamaan lain seperti Paskah, Nyepi, Galungan dan Kuningan juga ikut turut mendorong peningkatan kinerja ekspor jasa. Beberapa kegiatan Meeting, Incentive, Convention dan Exhibition (MICE) khususnya yang dilakukan oleh korporasi asing, juga mendorong peningkatan ekspor jasa. Peningkatan tersebut, seiring dengan mulai membaiknya pertumbuhan 
ekonomi beberapa negara tujuan ekspor Provinsi Bali, seperti kawasan Eropa dan Asia (China, Jepang dan ASEAN, serta Amerika Serikat). Ekonomi Maritim di Bali tergambarkan melalui peningkatan pertumbuhan volume ekspor Provinsi Bali terutama didorong oleh peningkatan kinerja volume ekspor untuk komoditas perikanan, komoditas produk olahan kayu, dan komoditas furniture yang memiliki share terhadap total ekspor Provinsi Bali masing-masing sebesar 26,6\%; 9,32\%; dan 6,87\%. Pertumbuhan kinerja ekspor komoditas perhiasan dan pakaian jadi (share 15,75\% dan 18,33\%) pertumbuhan volume ekspornya masih cenderung tertahan. Negara tujuan ekspor Provinsi Bali, masih didominasi oleh Amerika Serikat, Australia, Jepang, Singapura, dan Hongkong, dengan share masing-masing sebesar $24,5 \%, 9,3 \%, 8,53 \%$, dan 4,9\% (BI, 2016).

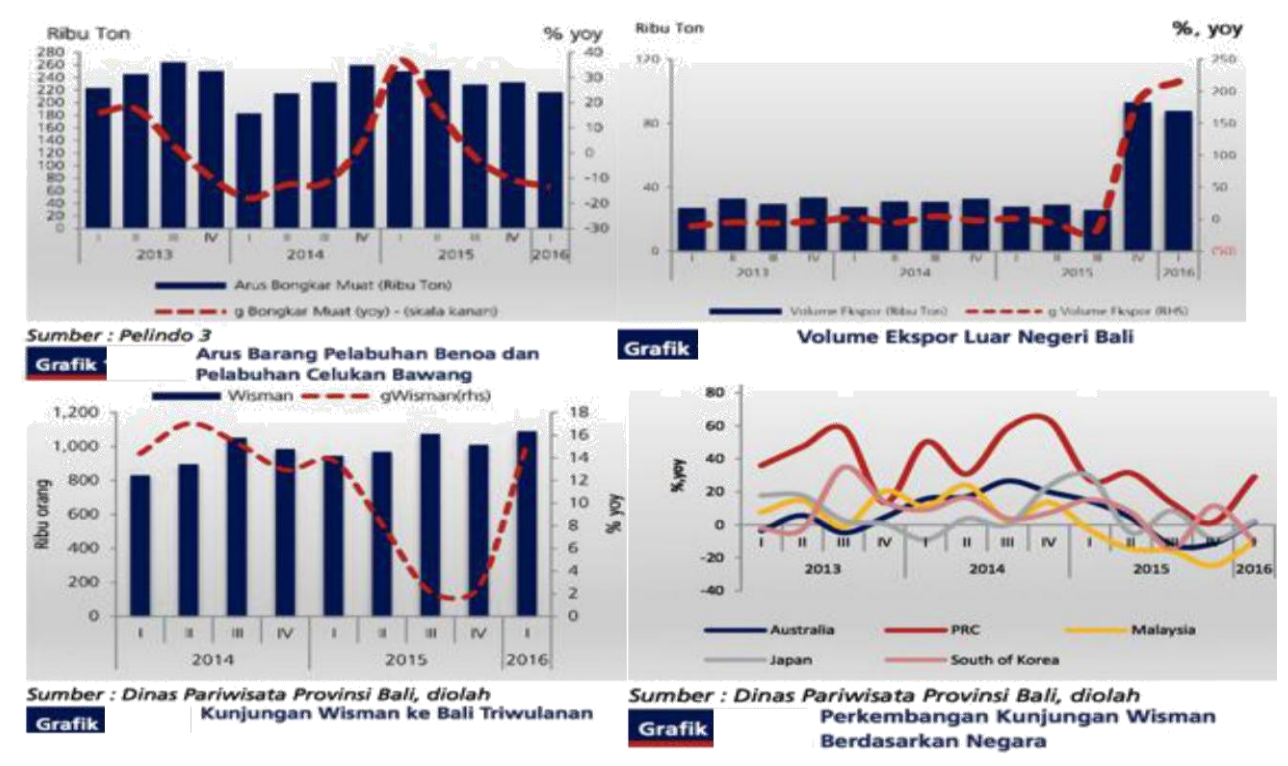

\section{Gambar 3. Pertumbuhan Ekonomi Pariwisata (Hotel \& Wisman) dan Maritim (Pelabuhan Benoa-Celukan Bawang) di Bali}

Pertumbuhan ekonomi Maritim dan Pariwisata di Indonesia Timur, khususnya di Provinsi Jawa Timur dan di Provinsi Bali harus dimanfaatkan secara optimal guna tercapainya kemakmuran daerah, dengan mengembangkan Model Integrasi Ekonomi Maritim dan Pariwisata. 


\section{B. Tinjauan Pustaka}

Pendapatan Daerah merupakan seluruh penerimaan yang berasal dari daerah itu sendiri maupun alokasi dari Pemerintah Pusat sebagai hak pemerintah daerah yang tidak perlu dibayar kembali oleh daerah. Sejak tahun 2008 hingga tahun 2013, pendapatan daerah mengalami pertumbuhan sebesar 75,3\% dari Rp. 365,1 Trilliun (tahun 2008) menjadi Rp. 640,2 Triliiun (tahun 2013). Namun pendapatan APBD tahun anggaran 2013 yang berasal dari non pajak dan retribusi masih sangat rendah (kurang dari 10\%), sehingga peningkatan kualitas pengelolaan kekayaan daerah mutlak ditingkatkan (Kemenkeu, 2013).

Kadin menyatakan proyeksi nilai kelautan Indonesia mencapai 171 miliar dollar AS atau setara dengan Rp. 2.046 triliun (Kurs Rp.12.000 per Dollar AS) yang meliputi: Perikanan Rp. 380 Triliun; Wilayah Pesisir Rp. 670 Triliun; Bioketnologi Rp. 480 Triliun; Wisata Bahari Rp. 24 Triliun; Minyak Bumi Rp. 252 Triliun; serta Transportasi Laut Rp. 240 Triliun (Kadin, 2015). Poros Maritim Dunia (PMD) yang bisa terwujud apabila ada Kebijakan dan Program pendukung yang Tepat, Efektif dan Kompetitif. TOL LAUT mendukung INDONESIA POROS MARITIM DUNIA 2045. Tol Laut adalah konektivitas laut yang efektif berupa adanya kapal yang melayari secara rutin dan terjadwal dari barat sampai ke timur Indonesia. (Bappenas, 2015)

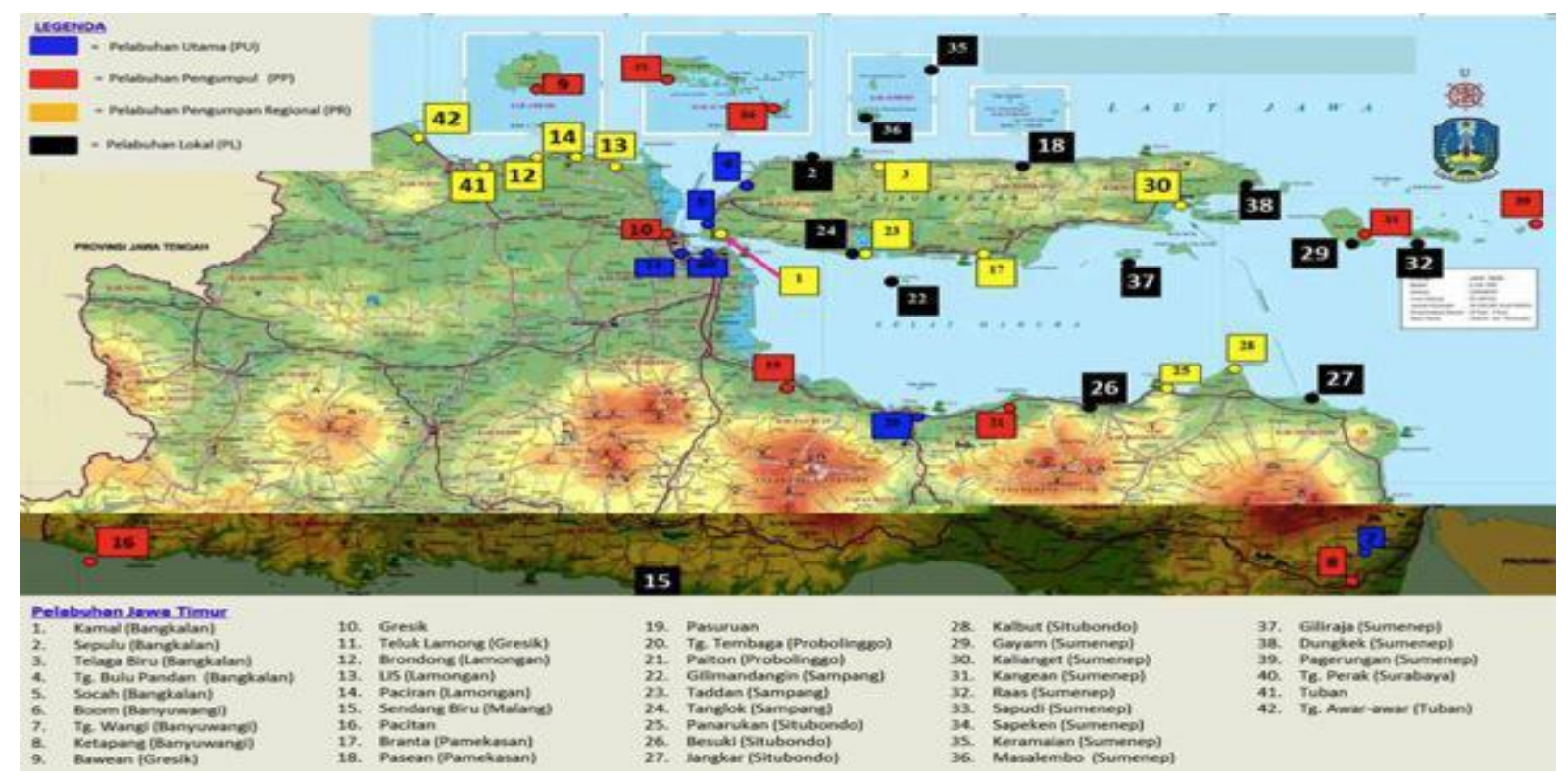

\section{Gambar 4. Pelabuhan Umum di Jawa Timur Sumber: Bappeprov Jatim, 2015}

Sistem Informasi Geografis (Geographic Information System / GIS) adalah sistem informasi khusus yang mengelola data yang memiliki informasi spasial (bereferensi keruangan). Atau dalam arti yang lebih sempit, adalah sistem komputer yang memiliki kemampuan untuk membangun, menyimpan, mengelola dan menampilkan informasi berefrensi geografis, misalnya data yang diidentifikasi menurut lokasinya, dalam sebuah database. Secara umum pengertian Sistem Informasi Geografis adalah Suatu komponen yang terdiri dari perangkat keras, perangkat lunak, data geografis dan sumberdaya manusia yang 
bekerja bersama secara efektif untuk memasukan, menyimpan, memperbaiki, memperbaharui, mengelola, memanipulasi, mengintegrasikan, menganalisa dan menampilkan data dalam suatu informasi berbasis geografis (Prahasta, Eddy, 2003 dalam Masudara, Jenry J, 2015). Menurut Pressman (Pressman, 2010 dalam Masudara, Jenry J, 2015), model waterfall adalah model klasik yang bersifat sistematis, berurutan dalam membangun software. Nama model ini sebenarnya adalah "Linear Sequential Model". Model ini sering disebut dengan "classic life cycle" atau model waterfall. Berikut adalah penjelasan dari tahap-tahap yang dilakukan dalam model Waterfall :

a) Komunikasi; Langkah ini merupakan analisa terhadap kebutuhan sistem. Pengumpulan data dalam tahap ini bisa malakukan sebuah penelitian, wawancara atau studi literatur.

b) Perencanaan; Tahapan ini akan menghasilkan jadwal atau rencana yang akan dilakukan dalam penelitian.

c) Pemodelan; Proses desain akan menerjemahkan syarat kebutuhan ke sebuah perancangan perangkat lunak yang dapat diperkirakan sebelum dibuat coding.

d) Konstruksi; Konstruksi merupakan tahapan pembuatan kode atau Coding. Coding merupakan penerjemahan design atau pemodelan dalam bahasa yang bisa dikenali oleh komputer. Setelah pengkodean selesai maka akan dilakukan testing terhadap sistem yang telah dibuat. Tujuan testing adalah menemukan kesalahan-kesalahan terhadap sistem tersebut dan kemudian bisa diperbaiki.

e) Penyerahan sistem ke para pelanggan/pengguna; Tahapan ini bisa dikatakan final dalam pembuatan sebuah sistem. Setelah melakukan analisa, design dan pengkodean maka sistem yang sudah jadi akan digunakan oleh $u$ ser.

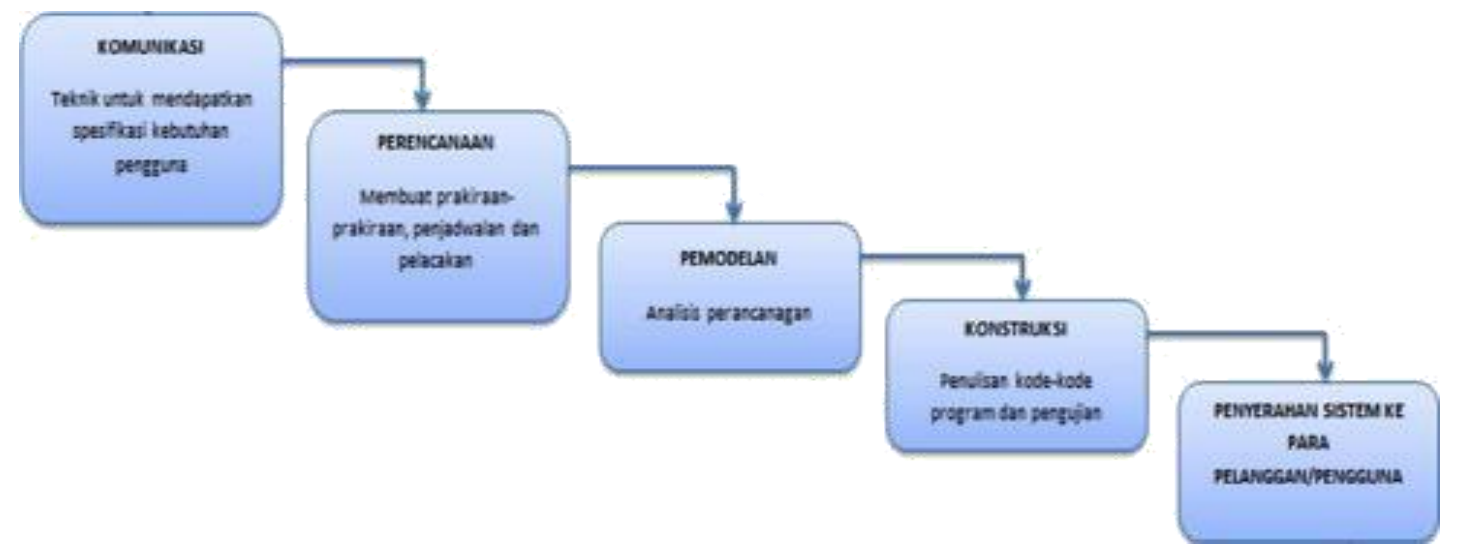

Gambar 5. Tahapan Pengembangan dengan metodologi waterfall (Roger S. Pressman) 


\section{STUDI PENDAHULUAN TELAH DILAKSANAKAN \& HASIL SUDAH DICAPAI, SERTA KETERKAITANNYA DENGAN USULAN PENELITIAN.}

\begin{tabular}{|c|c|c|c|}
\hline Tahun & Kegiatan Penelitian & Luaran & Indikator Capaian \\
\hline $\begin{array}{l}\text { Penelitian } \\
\text { Terdahulu } \\
\quad(2016)\end{array}$ & $\begin{array}{l}\text { Studi Kelayakan } \\
\text { Investasi dan Promosi } \\
\text { Wisata Maritim di Bali }\end{array}$ & $\begin{array}{l}\text { Seminar } \\
\text { Regional }\end{array}$ & $\begin{array}{l}\text { Tersedianya Laporan Studi } \\
\text { Kelayakan Investasi dan } \\
\text { Promosi Wisata Maritim di Bali, } \\
\text { dipublikasikan pada Seminar } \\
\text { Regional }\end{array}$ \\
\hline $\begin{array}{l}\text { Tahun I } \\
\text { (2017) }\end{array}$ & $\begin{array}{l}\text { Pengembangan } \\
\text { INTEGRASI Ekonomi } \\
\text { Maritim dan Ekonomi } \\
\text { Pariwisata di daerah }\end{array}$ & $\begin{array}{l}\text { Proceeding, } \\
\text { Seminar } \\
\text { Internasional } \\
\text { dan Jurnal } \\
\text { Terindex } \\
\text { Scopus }\end{array}$ & $\begin{array}{l}\text { Tersedianya Laporan Analisis } \\
\text { INTEGRASI Ekonomi Maritim } \\
\text { dan Ekonomi Pariwisata di } \\
\text { daerah, untuk kemudian } \\
\text { dipublikasikan pada Seminar } \\
\text { Internasional (Proceeding) dan } \\
\text { Jurnal Internasional terindex } \\
\text { Scopus }\end{array}$ \\
\hline $\begin{array}{c}\text { Tahun II } \\
\text { (2018) }\end{array}$ & $\begin{array}{l}\text { Sistem Informasi } \\
\text { Geografis INTEGRASI } \\
\text { Ekonomi Maritim dan } \\
\text { Ekonomi Pariwisata di } \\
\text { daerah }\end{array}$ & $\begin{array}{l}\text { HKI (Hak } \\
\text { Cipta) }\end{array}$ & $\begin{array}{l}\text { Tersedianya HKI Model } \\
\text { Aplikasi Sistem Informasi } \\
\text { Geografis INTEGRASI } \\
\text { Ekonomi Maritim dan Ekonomi } \\
\text { Pariwisata di daerah, Seminar } \\
\text { Internasional (Proceeding) dan } \\
\text { Jurnal Internasional terindex } \\
\text { Scopus }\end{array}$ \\
\hline
\end{tabular}

\section{Tujuan Dan Penelitian}

Tujuan penelitian, meliputi:

1. Melakukan pemetaan, perencanaan dan analisis kelayakan pengembangan Integrasi Ekonomi Maritim dan Pariwisata di daerah

2. Melakukan pengembangan aplikasi Sistem Informasi Geografis pengembangan Integrasi Ekonomi Maritim dan Pariwisata di daerah

Manfaat penelitian, meliputi:

1. Bagi pemerintah daerah, pengembangan Integrasi Ekonomi Maritim dan Pariwisata di daerah, akan sangat bermanfaat sebagai kajian akademik untuk percepatan peningkatan investasi di daerah

2. Bagi pemerintah daerah, Aplikasi Sistem Informasi Geografis Integrasi Ekonomi Maritim dan Pariwisata di Provinsi Jawa Timur dan Provinsi Bali, akan sangat bermanfaat bagi pemerintah daerah berupa produk Online yang dapat digunakan oleh guna mempercepat peningkatan investasi di daerah 
D. Metode Penelitian

\section{Gambar 6. Metode Penelitian}
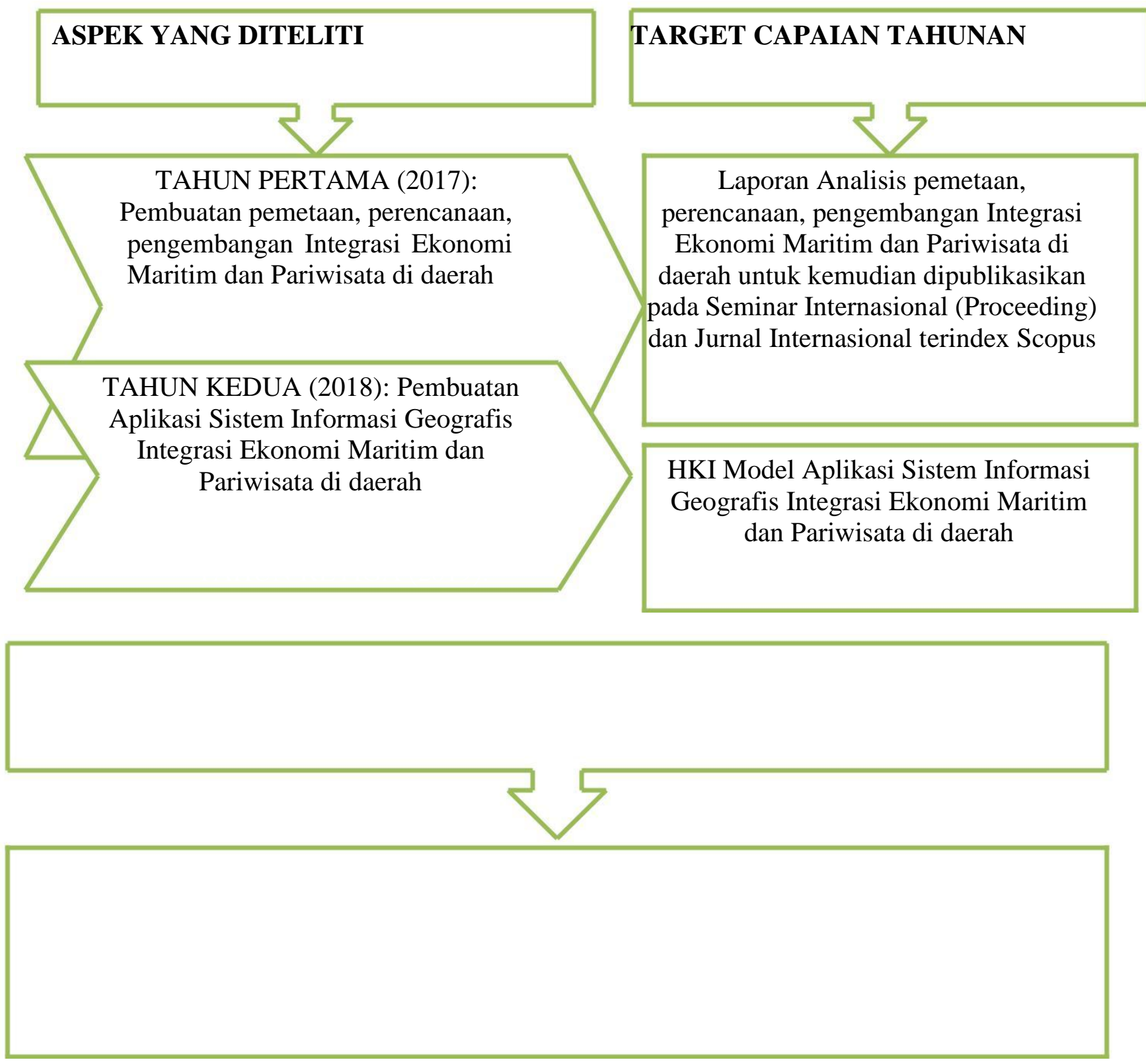


\section{HASIL YANG DICAPAI DARI KEGIATAN PENELITIAN HIBAH PPT:}

1. Laporan Analisis pemetaan, perencanaan, pengembangan Integrasi Ekonomi Maritim dan Pariwisata di daerah

2. Seminar Internasional (Proceeding) dan Jurnal Internasional terindex Scopus

3. HKI Aplikasi Sistem Informasi Geografis Integrasi Ekonomi Maritim dan Pariwisata di daerah

Tahun PERTAMA (2017) Membuat Analisis Integrasi Ekonomi Maritim dan Pariwisata di daerah, dengan melakukan pemetaan, identifikasi dan analisis pengembangan. Target capaian penelitian pada tahun pertama (2017) adalah Publikasi Ilmiah Internasional dan Pemakalah dalam Pertemuan Ilmiah Internasional berupa Proceeding, Seminar Internasional dan Jurnal terindex Scopus.

\section{E. Hasil Dan Luaran Yang Dicapai}

(1) PRESENTER dan PUBLIKASI BEREPUTASI (SCOPUS INDEXED)

International Conference ISKA17 di Johor, Malaysia

(INTERNATIONAL CONFERENCE ON ENGINEERING APPLICATION, PHYSICS AND SCIENCES - ICEAPS)

- Publikasi di JOURNAL Internasional Bereputasi Indexed Scopus: ADVANCED SCIENCE LETTERS

Pelaksanaan tanggal 26-27 July 2017 
Jurnal Darussalam; Jurnal Pendidikan, Komunikasi dan Pemikiran Hukum Islam

Vol. IX, No 1: 148-160. September 2017. ISSN: 1978-4767 (Cetak), ISSN: 2549-4171 (Online)

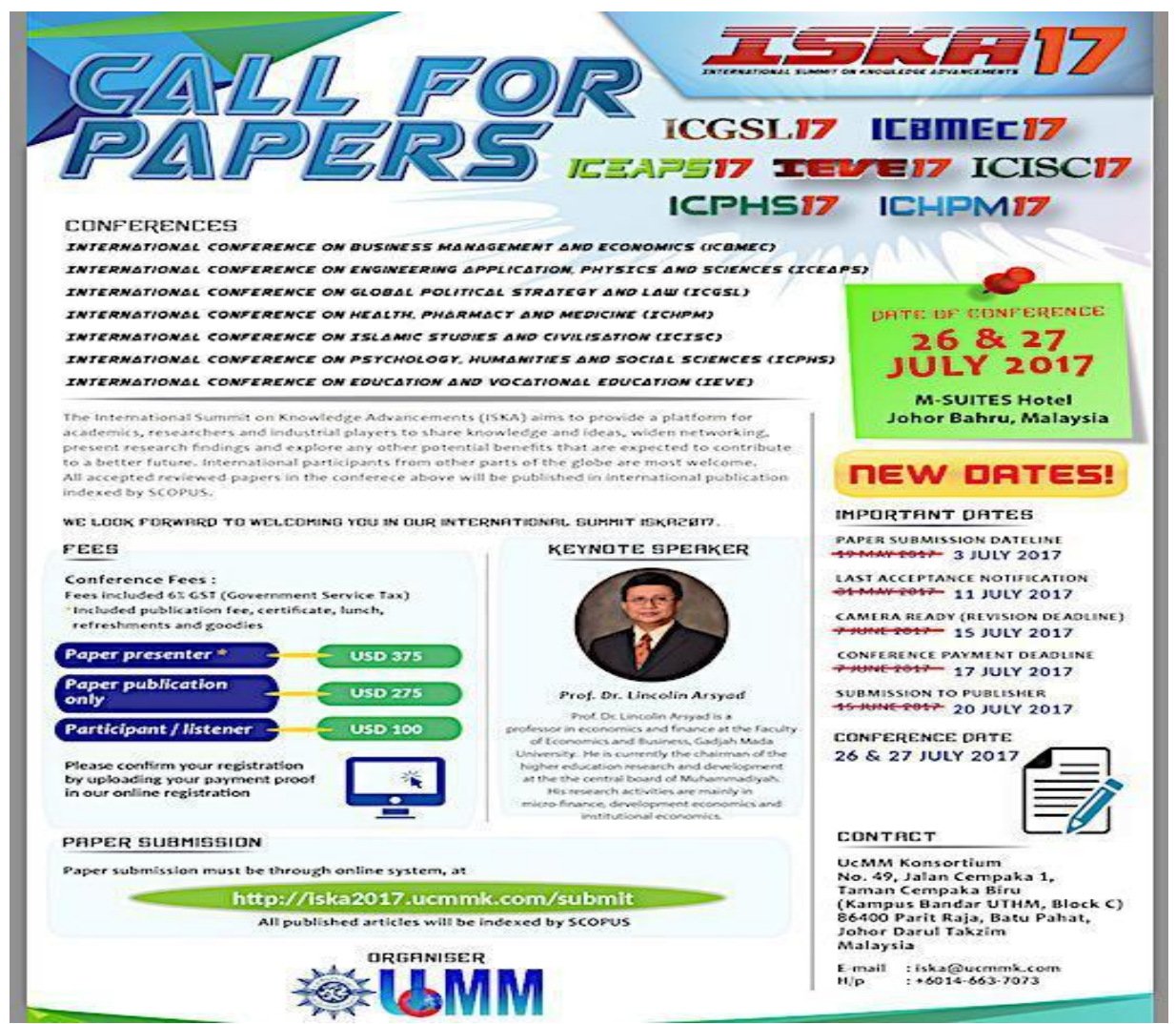

SJR Scimago Joumal \& Country Rank Enter Journal Title. Issi or Publisher Name

Home Journal Rankings Country Rankings Viz Tools Help About Us

\section{Advanced Science Letters}
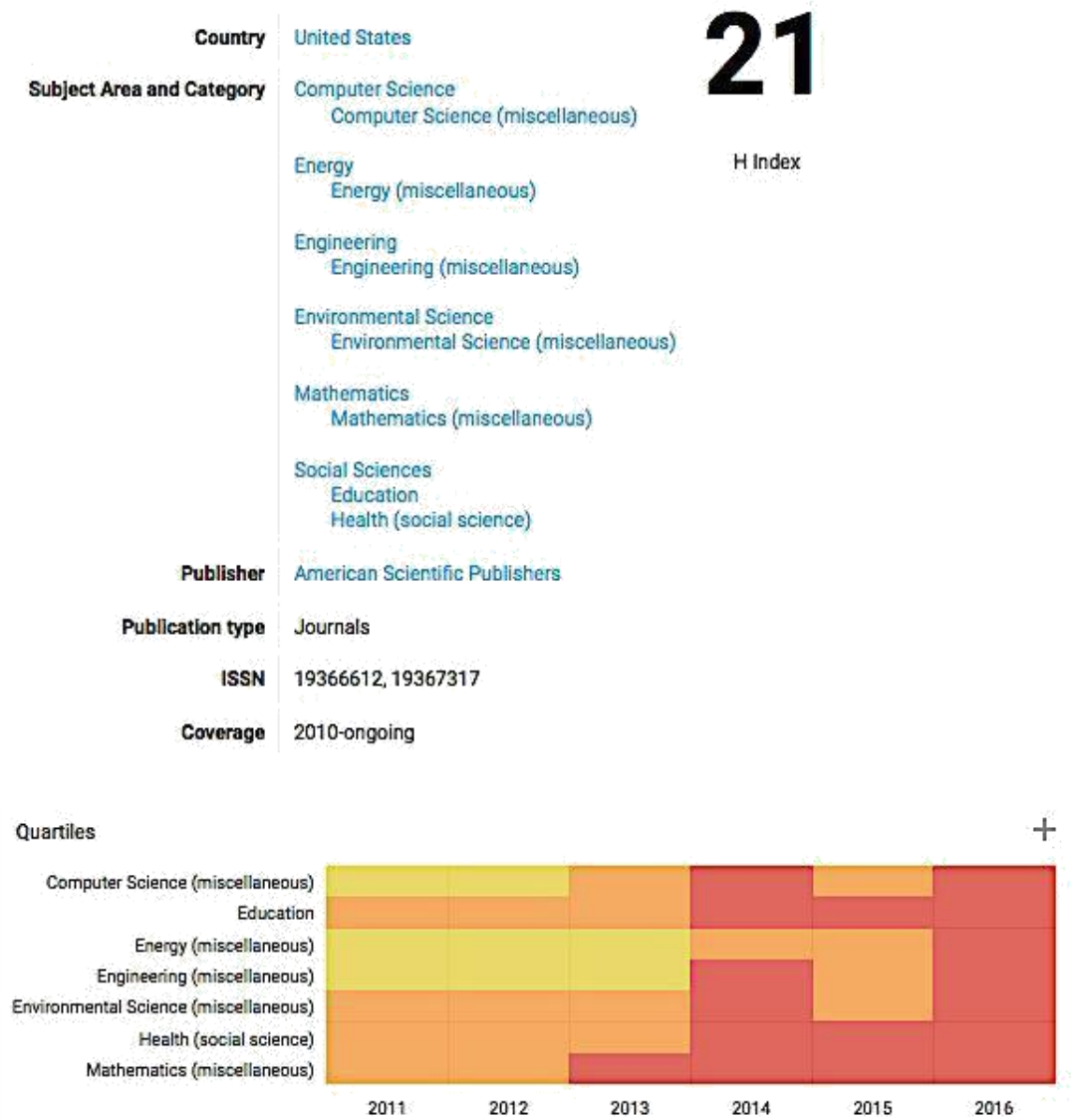


$\begin{aligned} & \text { Copyright } 92017 \text { American Scientific Publishers } \\ & \text { All rights reserved } \\ & \text { Printed in the United States of America }\end{aligned}$
AMERICAN
SCIENTIFIC

\title{
Development SME's Center Scheme Public-Private Partnership for Accelerating Improvement Of Regional Tourism Economic
}

\author{
INyoman Sudapet, M Ikhsan Setiawan, Agus Sukoco , Joko Suyono , Wahyu Mulyo Utomo? \\ ${ }^{1}$ Nárotama University, Surabaya, 60117 , Indonesia \\ UTHM, 86400 Parit Raji, Johor, Malaysià. \\ emait ikhsan setiawan(a narotama ac.id
}

\begin{abstract}
Infrastructure budget reached Rp. 290 trillion in APBN (State Budget-Changes) 2015 wass an opportunity for investors and government It would trigger an increase in tegional centers of digital SMEs, Indonesia Stock Exchatige in 2014 recorded a market capitalization (market cap) for the property sector, real estate, and construetion of buildings to reach $\mathrm{Rp} 360$ trillion (BEI, 2014) Bank Indonesia survey showed a significant increase in the selling price of strata titlè units in Greater Jakarta and Banten segments of office, retail, condominiums and industrial land, as: well as increased commercial property rental rates and hotel rates 3, 4 and 5 (BI, 2014). Régional autonomy through Law : No, 22/1999 anid 34/2004 made provineial and cities governments creative increase local reverue, APBD (local budget) in 2013 the area of financial deficit reached Rp 54.217 trilion (Ministry of Home Affairs, 2013 ) The development of regional centers of digital sMEs can be either collaboration between the centrali government, local government; state; enterprises; and private:

Keywords: regional center, digital SMEs, market capitalization; regional economic
\end{abstract}

(2) PRESENTER dan PUBLIKASI INTERNASIONAL (GOOGLE SCHOOLAR

\section{INDEXED)}

a) International Conference 14TH ADRI INTERNATIONAL CONFERECEN and CALL FOR PAPERS di Bali, Indonesia

ß) Publikasi di PROCEEDINGS Indexed Google Schoolar

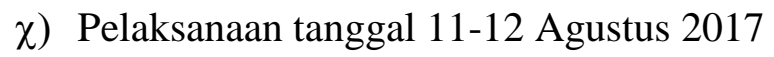




\title{
AIRPORT AND TOURISM, INCREASING REGIONAL ECONOMIC IN INDONESIA \\ I Nyoman Sudapet ${ }^{1}$, Agus Sukoco ${ }^{1}$, M Ikhsan Setiawan ${ }^{1}$ \\ INarotama University, Surabaya, Indonesia
}

\begin{abstract}
BPS (2015), Tourism becomes an important sector in Indonesian economy, not only as a source of foreign exchange earning but also to enlarge job opportunity and release income inequality. The richness of charming nature such as the beautiful nature, treasure of heritage, cultural uniquenes from the different ethnics, and a kind of atraction, festival, and cultural performance, becomes a great tourism potential for Indonesia. Tourism development programs should be increased by expanding and utilizing potency of national tourism to become an economic activity that can be expected to increase people's welfare. In addition,tourism can also introduce Indonesia to other countries, so that they are attracted to visit Indonesia. As we know number of travellers, both foreigners and domestic tourists continuously increase every year. This increase should be anticipated by the increase of hotels and other accommodation rooms, so it will meet demand and supply side of accommodation rooms. To give a good services related to accommodation facilities it needs a good planning in developing/increasing of hotels and other accommodation rooms, improving services quality and number of qualified accommodation workers, especially professional workers in hotels and other tourism facilities along with the increase of tourists staying in accommodation facilities Gu and Macdonald (2009), public infrastructure provides the geographic concentration of economic resources and wider and deeper markets for output and employment, affects the markets and resources of the finished product, helps to determine the spatial patterns of development and provides an extensive network of individual users at low prices, public infrastructure is generally seen as a foundation on which to build the economy
\end{abstract}

Keywords: Airport, Tourism, travellers, economic

\section{F. Kesimpulan}

(1) Pada tahun pertama (2017) pengembangan Integrasi Ekonomi Maritim dan Pariwisata di daerah telah dilakukan pemetaan, identifikasi-evaluasi kendala-kendala yang dihadapi, peluang dan strategi serta formulasi yang dapat dikembangkan.

(2) Berdasarkan analisis kelayakan tersebut, telah dihasilkan produk ilmiah meliputi:
a. Pemakalah dalam temu ilmiah internasional
b. Publikasi ilmiah internasional
c. Proses Hak kekayaan intelektual HKI berupa PATEN Hak Cipta
d. Proses Buku Ajar ISBN
e. Tingkat kesiapan teknologi TKT, LEVEL 5

DEFINISI/STATUS:

Kelengkapan dan Analisis Data pada Lingkungan Simulasi / Kegiatan Litbang INDIKATOR:

[1] Kehandalan data telah meningkat signifikan.

[2] Data telah cukup dan memenuhi syarat untuk analisis lanjutan.

[3] Analisis awal dengan data yang lengkap telah dilakukan

[4] Data diintegrasikan untuk analisis pengambilan kesimpulan 
[5] Laporan Kemajuan (analisis pendahuluan telah dihasilkan) dan rancangan output telah disusun.

\section{G. Saran}

Perlunya penambahan durasi lebih lama untuk penyelesaian PATEN Hak Cipta, disebabkan melibatkan lintas Kementerian, tidak hanya Kementerian RISTEKDIKTI tetapi juga Dirjen HAKI Kementerian KUMHAM

\section{Daftar Pustaka}

Aschauer, David A. 1989. Back of the G-7 pack: Public Investment and Productivity Growth in the Group of Seven. Working Paper Series. Macroeconomic Issues 89-13, Federal Reserve Bank of Chicago.

Atmaja, IBR Surya. 2001. Peranan Investasi Swasta, Investasi Sektor Publik dan Pertumbuhan Penduduk Terhadap Pertumbuhan GDP di Indonesia. Jurnal Ekonomi dan Bisnis Indonesia, Vol 15, No.2.

Badan Koordinasi Penanaman Modal. 2016. Realisasi Penanaman Modal PMDN-PMA Q42015. Jakarta: bkpm.go.id.

Bappeda Jatim. 2015. Transportasi Prasarana Perhubungan Jawa Timur. Badan Perencanaan Pembangunan Daerah Jawa Timur.

Badan Pusat Statistik. 2016. Indikator Ekonomi Maret 2016. Buletin Statistik Bulanan. BPS. ISSN 0126-2319.

Bank Dunia \& IFC. 2012. Doing Business di Indonesia: Membandingkan Kebijakan Usaha di 20 Kota dan 183 Perekonomian. Washington DC USA: The World Bank.

Bank Dunia \& IFC. 2013. Doing Business 2014: Understanding Regulations for Small and Medium-Size Enterprises. Washington DC USA: The World Bank.

Bank Indonesia. 2016. Laporan Nusantara, Kajian Ekonomi dan Keuangan Regional Bank Indonesia, vol.11, no.2, ISSN 2527-435X.

Bank Indonesia. 2016. Laporan Triwulan I-2016 Provinsi Jawa Timur. Kajian Ekonomi dan Keuangan Regional Bank Indonesia. Kantor Perwakilan BI Provinsi Jawa Timur.

Bursa Efek Indonesia. 2014. IDX Statistics 2013, BEI Research Divisions, idx.co.id.

Bursa Efek Indonesia. 2014. Performance Summary PT Pembangunan Jaya Ancol Tbk. idx.co.id Dirjen Keuangan Daerah Kemendagri, 2010, Neraca APBD 2010, Jakarta: Kementerian Dalam Negeri RI.

Dirjen Keuangan Daerah Kemendagri. 2013. Postur APBD Tahun Anggaran 2013. Jakarta: Kementerian Dalam Negeri RI.

Gulo, W. 2003. Metodologi Penelitian. Jakarta: PT Gramedia Widiasarana.

Indonesia Marzuki. 2002. Metodologi Riset. Yogyakarta: BPFE-UII.

Masudara, Jenry J, dkk. 2015. Sistem Informasi Geografis Perumahan di kota Manado Berbasis Web, e-journal Teknik Informatika, vol.6, no.1, ISSN 2301-8364.

Moleong, Lexy J. 2005. Metodologi Penelitian Kualitatif. Bandung: PT Remaja.

Rosdakarya PP no.6 tahun 2006 tentang Pengelolaan Barang Milik Negara/Daerah.

Rastogi, Tamboto, et.al. 2013. Asia's Next Big Opportunity: Indonesia's Rising Middle-Class and Affluent Consumers. The Boston Consulting Group, bcg.com.

Tiffin R. 1999. Practical Techniques for Effective Project Investment Appraisal. Hawksmere PLC Todaro, M.P. 1997. Pembangunan Ekonomi di Dunia Ketiga. Ghalia. Jakarta: UU no.22 Tahun 1999 \& UU no.34 tahun 2004 tentang Otonomi Daerah.

Yin, R.K. 2009. Case Study Research. Design and Methods, 4. Ed, Thousand Oaks, California. 